\title{
УКРАЇНСЬКА РОМАНТИЧНА ПОЕЗІЯ: СИМВОЛІКА ОБРАЗУ КОНЯ
}

\author{
СВІТЛАНА ГАЙДУК \\ Природничо-гуманітарний університет в м. Сєдльце, Сєдльце - Польща \\ hayduksvitlana79@gmail.com; ORCID: 0000-0002-1012-6091

\section{UKRAIŃSKA POEZJA ROMANTYCZNA: SYMBOLIKA OBRAZU KONIA} \\ SVITLANA HAYDUK \\ Uniwersytet Przyrodniczo-Humanistyczny w Siedlcach, Siedlce — Polska
}

\begin{abstract}
STRESZCZENIE. W artykule został przeanalizowany obraz konia w twórczości ukraińskich poetów romantyków na tle europejskiej tradycji pisania w świetle jego symbolicznych oraz mitologicznych paradygmatów. Podkreśla się, że w ukraińskiej romantycznej poezji symbolika obrazu konia bezpośrednio koreluje z symbolem wolności, ponieważ koń jako obraz poetycki jest „istotą obdarzoną duszą”. Wolność symbolizują jego działania, czyli pęd, dziki galop lub spokojna wędrówka (wiersz Козак Ł. Borowykowskiego, ballada Кiнь M. Kostomarowa). Zauważono, że obraz konia działa jako symbol wierności i piękna. Potrafi się wczuć w romantycznego bohatera, przestrzec go przed niebezpieczeństwem (poemat Гайдамаки, ballada Причинна Т. Szewczenki, wiersz Козак Ł. Borowykowskiego, До коня W.Zabiły, Украинская дума O. AfanasjewaCzużbińskiego). Jednak obrazy koni mogą również symbolizować mroczne siły natury. Niosą one jeźdźca w nieznane, ucieleśniają negatywną energię (poemat satyryczny Сон T. Szewczenki).
\end{abstract}

Słowa kluczowe: obraz konia, symbol, ukraińscy poeci epoki romantyzmu, paradygmat

\section{UKRAINIAN ROMANTIC POETRY: SYMBOLISM OF THE HORSE}

\section{SVITLANA HAYDUK}

Siedlce University of Natural Sciences and Humanities, Siedlce — Poland 
ABSTRACT. The article focuses on the analysis of the horse image in the works of the Ukrainian Romantic poets which is based on the European tradition of writing in view of its symbolic and mythological paradigms. It is emphasized that in the Ukrainian Romantic poetry the horse image directly correlates with the symbol of freedom, because the horse as a poetic image is ,the creature endowed with a soul". Because of its actions, such as galloping or wandering, the horse image becomes a symbol of freedom (poetry Kozak by L. Borovikovsky, ballad Kin by M. Kostomarov). It is noted that the horse image is a symbol of fidelity and beauty. It is able to empathize with a Romantic hero, to warn him of danger (poem Haidamaky, ballad Prychynna by T. Shevchenko, poetry Kozak by L. Borovikovsky, Do konia by V.Zabila, Ukrainskaya duma by O. Afanasiev-Chuzhbinskyi). However, the horse images can also symbolize the dark forces of nature. They carry a rider into the unknown and embody negative energy (satirical poem Son by T. Shevchenko).

Key words: horse image, symbol, Ukrainian Romantic poets, paradigm

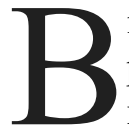
ідображення символіки освоєної фауни глибоко споріднене із суттю романтичної ідеології, традиції якої відтворені й у сучасних художніх творах. Ідеться про визначальні тематичні мотиви, що акцентують В українській романтичній поезії символіку образів коня, собаки та півня. 3-поміж трьох названих представників свійських тварин образові коня відведено чільну роль - утілення особливостей романтичного світогляду й романтичної ідеології. Саме тому в літературі та живописі доби романтизму образ коня превалює. Його символіка пов'язана насамперед з романтичним почуттям свободи героя-вершника на безкраїх просторах степу. Наголосімо, що образи освоєної фауни в поезії епохи романтизму переосмислювалися в поетичних текстових структурах не тільки у фольклорному та античному контекстах, але й у біблійному. Тому так важливо розглядати образ коня у творчості українських поетів-романтиків на тлі європейської традиції письменства $з$ огляду на його символічну та міфологічну парадигми.

Образ коня як анімалістичний символ найбільшою мірою відповідає поетичним настроям періоду романтизму. На думку М. Епштейна, „образ коня, висунутий у центр ліричної творчості романтичним світовідчуттям, що прийшло на зміну класичній дидактиці, $\mathrm{i}$, подібно до багатьох інших романтичних нововведень, закріпився в ліриці як ії стійка емблема" [Эпштейн 1990: 92-93] (переклад автор. - С. Г.). Чільне місце коня в системі анімалістичних образів романтичної поезії зумовлене двома обставинами. 3 одного боку, кінь - це свійська тварина, що дуже близька людині, а його символіка пов'язана із зародженням цивілізації й господарювання. 3 другого боку, кінь, як жодна інша свійська тварина, уособлює неприборканість, незалежність, свободу. Власне на цьому парадоксі значень сформувалася романтична символіка коня, у якій семантика волі, свободи, дикої природи є провідною [Гайдук 2011: 12]. Саме в такому руслі проінтерпретуємо образи коней у поетичних творах Т. Шевченка, М. Костомарова, Л. Боровиковського, В. Забіли, О. Афанасьєва-Чужбинського. 
Образові коня в культурі загалом і в літературі зокрема присвячені такі праці: польського науковця М. Чапського Загальна історія коня (Historya powszechna konia) у трьох томах, що побачила світ 1874 р. в Познані; антологія Л. Гінкової Кінь має в собі душу (Koń ma duszę w sobie, 1988); книга Б. Сібона Кінь Мазепи (Le Cheval de Mazeppa, 2006); колективна монографія Кінь у мові, літературі і культурі (Koń w języku, literaturze i kulturze), видана 2016 р. в Сєдльці. Важливість ролі цього символу для естетики та поетики романтизму засвідчує також спеціальна стаття, присвячена образу коня у виданні Словник польської літератури ХІХ століття (Stownik literatury polskiej XIX wieku, 1994).

Для повноцінного інтерпретування символіки образу коня у творах українських поетів-романтиків важливо враховувати його значення в міфологічних, релігійних та фольклорних джерелах. Так, у словниках символів традиційно зазначається, що кінь — це один з найвірніших товаришів людини. Він утілює позитивну життєву силу, хоч може бути також і носієм негативної енергії. Тут слід зазначити, що в міфології коні часто впряжені в колісниці різних богів. Вигляд і колір коня нерідко уособлюють його певні індивідуальні характеристики й, очевидно, сутність зв'язків з богом. Приміром, світлий кінь - це символ позитивних сил. Від стародавніх часів білий колір уважають кольором святих, тому тварин білої масті приносили в жертву небесним богам, а темної - богам темного (підземного) світу. Саме тому колісницю Сонця тягнуть білі коні як символи життя, денного світла, духовного просвітлення, перемоги й тріумфу. Натомість чорні коні (утілення зловісної нічної темряви, нечистої сили й смерті) скачуть у колісниці Плутона - бога підземелля [Вовк 2006: 210-211].

Розглядаючи символіку образу коня в слов'янській міфології, звернімо увагу на факти, що наведені в розвідці Слов 'янська міфологія М. Костомарова. Тут автор детально описує способи та причини возвеличення коня давніми слов'янськими племенами. Кінь був єдиною твариною, яку полабські слов'яни вважали священною. У місті Радгості (Ретрі) був храм бога Сварога. Під час богослужінь обрані мешканцями люди проводили ворожіння, головним атрибутом яких був кінь: „[...] прикрасивши зеленими гілками коня, якого вважали священним, проводили його через списи, запхані в землю, навхрест одне до другого" [Костомаров 1994: 202]. Коли ворожіння віщувало добру новину, то розпочинали справу, якщо ж звістка не була доброю, то полишали свої наміри. Але не всі міфічні коні $є$ носіями добра. Деякі з них смертельно небезпечні для вершника. Це стосується передусім чорних коней-перевертнів. Їхню подобу люблять приймати чорти, гобліни та інша нечиста сила. Такому диявольському створінню легко скинути вершника в безодню чи просто загризти. Розпізнати коня-перевертня нескладно: „у нього зуби вовка, а очі горять пекельним вогнем” [Вовк 2006: 210-211]. 
У фольклорі та героїчному епосі коні, наділені чудодійними властивостями, вірою й правдою, служать легендарним героям, допомагаючи здійснювати дивовижні подвиги. У казці про козака Дрімсона мудрий кінь завбачливо радить козаку не чіпати знайдене перо чарівного птаха, бо буде біда. Згодом кінь допомагає неслухняному Дрімсону впіймати самого птаха, знайти панну, якій належить птах, а потім і “табун коней”, за яким тужить панна. Про такого коня народна мудрість каже: „Доброму коневі хвате доброго слова”, „Доброму коневі малахай не нужен” [Шалак 1994: 134].

Відомо, що релігійна символіка надає коневі й позитивне, і негативне значення. У негативному розумінні образ коня використовують для зображення пихи певного героя. Ця риса характеру персоніфікувалася як особа, скинута з коня, і особливо часто фігурувала на середньовічних полотнах, на яких зображали сім головних гріхів [Impelluso 2006: 257]. Кінь може символізувати також недосконалість, глупство: „[...] для спасіння той кінь не надійний, і великістю сили своєї він не збереже" (Пс. 33.17) [Біблія...] чи „Не будьте, як кінь, як той мул нерозумні, що їх треба приборкати оздобою їхньою - вудилом і вуздечкою...” (Пс. 32.9) [Біблія...]. У позитивному значенні кінь - атрибут ангела, порівн.: „Бачив я цієї ночі, аж ось на червоному коні їде муж, і він стоїть між миртами, що в глибині, а за ним коні червоні, руді та білі" (Зах. 1.8) [Біблія...]. Він також утілення мужності, шляхетності і $є$ емблемою святих Георгія, Мартина, Маврикія, Віктора, а дикі коні- емблема святого Іпполіта.

У дослідженні спираємося на зазначені контексти, у яких відстежуємо властиві романтикам звернення до міфологічних, фольклорних та релігійних джерел минулого. У поетичних текстах українських романтиків наскрізною $€$ думка про те, що здатність коня передбачити майбутнє ставить його вище за людину. Адже він може проникати поза межі реального світу. Кінь може передбачити нещастя, зупинитися перед невидимою для вершника перешкодою, злякатися примари. Передчуття конем біди символічно виражається різними діями: важкою ходою, спотиканням, пручанням. Саме таку ситуацію відтворено в баладі Причинна (1837) Т. Шевченка (1814-1861): спотиканням кінь попереджає козака про нещастя, що трапилося з його коханою, і віщує близьку смерть свого господаря. Світлому образові коня протиставлено символ темряви - гадину, порівн.: .... А тим часом із діброви / Козак виїжджає; / Під ним коник вороненький / Насилу ступає. / ... Утомився вороненький, / Іде, спотикнеться, - / Коло серия козацького / Як гадина в'ється. / ...ІІуть під дубомзелененьким /Кінь замордований стоїть, / А біля його молоденький / Козак та дівчина лежить... [Шевченко 2003: 1]. У цих рядках проступає відгомін фольклорної традиції, що, за твердженням А. ГорняткоШумилович, „у поетичній спадщині Тараса Шевченка яскраво виражена” [Горнятко-Шумилович 2016: 211]. 
Опис аналогічної ситуації знаходимо також у вірші Розставання українського поета, фольклориста та етнографа Л. Боровиковського: ...Кінь під тобою вороний сумує — / Кінь вороненький недоленьку чує... [Українські поети-романтики 1968].

У баладі Кінь зі збірки Украӥнські балади (1838) М. Костомарова йдеться про те, що вірний кінь став убивцею господаря-пана. Тварина пручалася, подавала зловісний знак-пересторогу: ...Пан коня звертає, наліво зайжджає, / А кінь завертиться й не йде... [Костомаров 1990, 1: 59-60]. Однак господар не зрозумів попередження, не захотів повертатися додому. В останніх рядках балади простежуємо мотив моральної вищості нижчої істоти над паничем, що підкреслено синтаксичним паралелізмом та контекстуальними протиставленнями: ...Був пан колись добрий, чесний та хоробрий, - / Лукавий на лихо підвів! / Був кінь колись вірний, в послузі незмінний, - / В розбої служить не схотів!.. [Костомаров 1990, 1: 59-60].

На особливу увагу в українській романтичній поезії заслуговують слова-звертання ліричного героя до коня. На думку В. Філіпп, „у звертаннях до коней емоційність поетів-романтиків відіграє не меншу роль, ніж у звертаннях до людей” [Филипп 1988: 123-128] (переклад автор. - С. Г.). Залежно від ситуації, характеру й настрою господаря коня ці звертання можуть бути позитивними, дружніми, ласкавими чи лайливими, тобто виражати різні емоції. Саме звертання, особливо якщо вони експресивно забарвлені, емоційно “зрівнюють” коней $з$ людьми.

Такі звертання трапляються часто й у текстах українських поетів-романтиків. Зокрема, В. Забіла у поезії До коня (1841) використовує присвійний займенник та епітет “добрий” у зверненні до вірного приятеля людини: Що, мій коню, що, мій добрий [Українські поети-романтики 1968]. А у творі Украинская дума (1839) О. Афанасьєва-Чужбинського кінь для молодого козака це вірний товариш, який не покинув його, пораненого, на полі бою. Він угамував своїми сльозами спрагу господаря, відігнав степового орла, бо той збирався поклювати знесиленого козака, та іржанням прикликав інших козаків, а потім остался по гроб ему другом [Українські поети-романтики 1968].

Відтворення в текстах творів ситуацій зі звертаннями розкривають одну із центральних рис романтичного світогляду — сприйняття природи як цілісного живого організму, а відтак, і ставлення до тварин, як до рівних людині істот (а почасти й вищих, не зіпсованих цивілізацією). Водночас наведені приклади засвідчують мрію українських поетів-романтиків повернути втрачену гармонію між людиною й природою (вершником і конем).

У творах постромантичних часів коня вважали символом епохи романтизму. Цей виразний факт відстежуємо на сторінках поеми Лісова ідилія (1903) I. Франка, де поет поєднує образ коня з романтичною концепцією світу: $\mathrm{Ha}$ романтичного коня сідаю. / Крилатий звіру, не пручайсь, не ржи! / Неси 
мене, куди я загадаю, / На фантастичні ті шпилі біжи, / Де вихор грає, стогне гомін гаю, / Де на вузькій, мов ниточка, межі / Фантазія і дійсність спина в спину / Глядять у мрій квітчастую крайну... [Франко 1976, 3: 107].

Для I. Франка осідлання романтичного коня означає передусім звернення до романтичної поетики, романтичного настрою, а в широкому розумінні до романтичної концепції художнього світу. Образ коня в поемі І. Франка можна пов'язати також із відомим крилатим конем грецьких міфів - білосніжним Пегасом, що з'явився на світ з тулуба вбитої Персеєм горгони Медузи. На горі муз, Геліконі, Пегас вибив копитом чудотворне джерело Іппокрена. Завдяки цьому став поетичним символом натхнення й символом-образом поетів. Уважалося, що метафоричний образ Пегаса як обдарованого поета підносить творців на вершину Парнасу — в оселю муз [Вовк 2006: 210-211]. Використання такої символіки образу коня було поширене й у західноєвропейській, і в українській романтичній традиції.

Однією з важливих рис образу романтичного коня є те, що він - істота красива, граціозна. Майже в кожному поетичному тексті містяться його описи, де йдеться про привабливий зовнішній вигляд тварини. Проте не краса робить образ романтичного коня винятковим у світлі символічної парадигми бестіарію. Л. Гінкова доречно стверджує, що „кінь має в собі душу, яка відчуває свою енергійність і засмучується, що творець ув'язнив ії в тілі тварини" [Ginkowa 1988: 11-12] (переклад автор. - С. Г.). Саме завдяки душі, ув'язненій у тілі коня, можливий такий художньо вірогідний контакт з вершником. В українській романтичній поезії кінь може проникати в думки свого господаря, поділяти його почуття, співпереживати. Власне через те, що романтичний герой часто перебуває в ситуаціях конфлікту з довкіллям, самотності, а також внутрішньої поразки, у нього немає нікого ближчого за співчутливого коня. Наведімо приклад з поеми Гайдамаки (1841) Т. Шевченка: ...Не дослухав... „Неси, коню!” / I поводи кинув. / „, Чом я вчора, поки не знав, / Вчора не загинув!.." / ...Замовк, зажурився, / Пойхав ходою. / Тяжкк-важко сіромасі/ Боротись з нудьгою... [Шевченко 2003: 1].

У контексті романтичної символіки змістовно інтерпретовано образ коня в сатиричному творі Сон (1844) Т. Шевченка: ...От я повертаюсь - / Аж кінь летить, копитами / Скелю розбиває! / ... Кінь басує - от-от річку, / От... от... перескочить. / А він руку простягає, / Мов світ увесь хоче / Загарбати... [Шевченко 2003, 1]. Слова він руку простягає, мов світ увесь хоче загарбати натякають на пам'ятник Петру І на Сенатській площі в Петербурзі, що споруджено 1782 р. за проєктом французького скульптора Е. Фальконе. Стилістично знижений опис пам'ятника суперечить офіціозно закладеній у ньому величі. У цьому разі спостерігаємо кардинально іншу символіку коня. Вона пов'язана передусім із семантикою та символікою вершника - Петра I. Оскільки Т. Шевченко використовує образ Петра I з негативною коно- 
тацією, то підтекст з пейоративним значенням частково переноситься й на його коня. У творі виокремлюємо типологійну паралель: символіка образів вершника - Петра I - i його коня є абсолютно протилежною щодо поеми Мідний вершник (Медный всадник) О. Пушкіна. Це пояснюється тим, що T. Шевченко та О. Пушкін презентують різні національні ідеології: О. Пушкін — імперської Росії, Т. Шевченко — підневільної України.

Поетичним образом вершника, який галопом мчить у далечінь, часто $\epsilon$ незвичайна, чуттєва особистість, яка глибоко розуміє світ. Саме через це довкілля для типового романтичного героя стає джерелом постійного розчарування, від якого ілюзорно врятувати може втеча на коні. Мотив цієї втечі простежуємо у вірші Козак Л. Боровиковського, у якому зображені фольклорні образи ворона, сарани, коня, nса, орла, порівн.: Не стаями ворон літає в полях, / Не хліб сарана витинає, / ...То турок, то нехрист 3-за моря летить / І коней в Дунаї купає; / Йде в город - в чумі мов весь город лежить, / Селом - і село западає... // Широкую гриву на вітер пускай, / Неси мене, коню, за бистрий Дунай! // Неси мене, коню, заграй під сідлом, / За мною ніхто не жаліє. / Ніхто не заплаче, ніхто з козаком / Туги по степу не розсіє. / Чужий мені край свій, чужий мені світ, / За мною сім'я не заниє, - / Хіба тільки пес мій, оставшись в воріт, / Голодний, як рідний, завиє!.. // А може, поляжу й сам серед степів / 3 тобою, ти, вірниймій коню? /Широким я тілом згодую орлів, / А кровію моря доповню... [Боровиковський 1971: 46-47].

Дикий галоп коня символізує спробу втечі від довкілля, намагання забути про нього й про проблеми, які воно уособлює. I українські, i західноєвропейські поети-романтики розглядали цю ситуацію як можливість, що допомагає героєві самовизначитися, перевірити власну цінність, усвідомити власні можливості. Нерідко образ вершника в поезіях епохи романтизму характеризують через змалювання надшвидкої їзди, що свідчить про переживання ним, приміром, відчуття тривоги.

Традиційні народні мотиви - неси мене, коню, за бистрий Дунай; широким я тілом згодую орлів; хіба тільки пес мій, як рідний завиє - уплетені в складний ліричний сюжет, а символіка фауни презентує романтичну ідеологію. Ї̈ї складники - свобода й воля (символіка коня), екзистенційні почуття самотності (голодний пес), відчуття близької смерті (ворон).

У проінтерпретованих творах українських поетів-романтиків символіка образу коня безпосередньо співвідноситься із символікою свободи, адже кінь як поетичний образ - це “наділена душею істота”. Свободу він символізує своїми діями, тобто бігом чи блуканням (поезія Козак Л. Боровиковського, балада Кінь М. Костомарова). Крім цього, згадаймо й образ коня як символ вірності та краси. Він здатний співпереживати з романтичним героєм, попереджати про небезпеку (поема Гайдамаки, балада Причинна Т. Шевченка, поезії Козак Л. Боровиковського, До коня В. Забіли, Украинская дума О. Афа- 
насьєва-Чужбинського). Образи коней можуть символізувати й темні сили природи. Вони несуть вершника в невідоме, утілюють негативну енергію (сатирична поема Сон Т. Шевченка).

Образи освоєної та дикої фауни в українській романтичній поезії стали репрезентантами стрижневих аспектів символічної парадигми романтичного бестіарію, цінностей та ідей романтичного світовідчуття. Звісно, символіка фауни не охоплювала всього розмаїття романтичного світосприйняття. Українські поети-романтики нерідко поєднували її з іншими типами символів (символіка рослин, чисел, кольору).

\section{Список використаної літератури}

Гайдук С. Є., Образ коня у поетичних структурах Михайла Лермонтова, [в:] „Наукові записки Харківського національного педагогічного університету імені Г. С. Сковороди. Сер.: Літературознавство", 2011, вип. 4 (68), ч. 1, с. 12-15.

Горнятко-Шумилович А., Символ тополі в поезії Тараса Шевченка, [в:] „Studia Ukrainica Poznaniensia", 2016, zesz. IV, s. 211-216.

Костомаров М. І., Слов'янська міфологія: вибрані праці з фольклористики й літературознавства, Київ: Либідь, 1994.

Украӥнські поети-романтики 20-40-х років XIX ст., вступ. сл. проф. І. Айзенштока, Київ: Дніпро, 1968.

Филипп В., Эй, выл, залетныле!, [в:] „Studies in Slavonic literatures and culture”, 1988, с. 23 128.

Шалак О., Кінь, [в:] Українські символи, Київ: Ред. часопису „Народознавство”, 1994, с. 134. Эпштейн М. Н., , Природа, мир, тайник вселенной... ”: система пейзажных образов в русской поэзии, Москва: Высшая школа, 1990.

Ginkowa Ł., Koń ma duszę w sobie, Kraków, 1988.

Impelluso L., Natura i jej symbole, Warszawa: Arkady, 2006.

\section{Spysok vykorystanoi literatury [References]}

Haiduk S. Ye., Obraz konia u poetychnykh strukturakh Mykhaila Lermontova [Horse Image in the Poetic Structures of Mikhail Lermontov], [v:] „Naukovi zapysky Kharkivskoho natsionalnoho pedahohichnoho universytetu im. H. S. Skovorody. Seriia: Literaturoznavstvo", 2011, vyp. 4 (68), ch. 1, s. 12-15.

Horniatko-Szumiłowicz A., Symvol topoli v poezii Tarasa Shevchenka [The Symbol of Poplar in Taras Shevchenko's Poetry], [v:] „Studia Ukrainica Poznaniensia”, 2016, zesz. IV, s. $211-216$

Kostomarov M. I., Slovianska mifolohiia: vybrani pratsi z folklorystyky y literaturoznavstva [Slavic Mythology: Selected Works on Folklore and Literary Criticism], Kyiv: Lybid, 1994.

Ukrainski poety-romantyky 20-40-kh rokiv XIX st. [Ukrainian Romantic Poets of 20-40-ies of the XXth century], vstup. sl. prof. I. Aizenshtoka, Kyiv: Dnipro, 1968. 
Filipp V., Ej, vy, zaletnye! [Hey, You, Stray!], [v:] „Studies in Slavonic literatures and culture”, 1988, s. 123-128.

Shalak O., Kin [Horse], [v:] Ukrainski symvoly, Kyiv: Red. chasopysu „Narodoznavstvo”, 1994, s. 134.

E'pshtejn M. N., „Priroda, mir, tajnik vselennoj...”': sistema pejzazhnyx obrazovv russkoj poe'zii ["Nature, the World, the Secret of the Universe. ": a System of Landscape Images in Russian Poetry], Moskva: Vysshaya shkola, 1990.

Ginkowa Ł., Koń ma duszę w sobie [Horse Has a Soul], Kraków, 1988.

Impelluso L., Natura i jej symbole [Nature and Its Symbols], Warszawa: Arkady, 2006.

\section{Список використаних джерел}

Афанасьев-Чужбинский А. С. Украинская дума, [в]: Его же, Собр. соч., в 9 томах, т. 9: Стихотворения, С.-Петербург: Изд-е Германа Гоппе, 1893.

Біблія або Книги Святого Письма Старого й Нового Заповіту, Київ: Українське біблійне товариство, 1991.

Боровиковський Л., Твори, Київ: Вид-во ЦК ЛКСМУ „Молодь”, 1971.

Вовк О. В., Энииклопедия знаков и символов, Москва: Вече, 2006.

Забіла В., До коня, [в]: Украӥнські поети-романтики. Поетичні твори, Київ: Наукова думка, 1987.

Костомаров М. І., Твори, у 2 томах, упоряд., авт. передмови та приміт. В. Л. Смілянська, Київ: Дніпро, 1990, т. 1.

Франко І. Я., Зібр. творів, у 50 томах, т. 3, ред. П. Й. Колесник, Київ: Наукова думка, 1976.

Шевченко Т. Г., Повне зібр. творів, у 12 томах, редкол. М. Жулинський та ін., т. 1, Київ: Наукова думка, 2003.

\section{Spysok vykorystanykh dzherel}

Afanas'ev-Chuzhbinskij A. S., Ukrainskaya duma [Ukrainian Duma], [v]: Ego zhe, Sobr. soch. [Collected Works], v 9 tomax, t. 9: Stixotvoreniya [Poems], S.-Peterburg: Izd-e Germana Goppe, 1893.

Bibliia abo Knyhy Sviatoho Pysma Staroho y Novoho Zapovitu [The Bible or the Book of Scripture of the Old and New Testament], Kyiv: Ukrainske bibliine tovarystvo, 1991.

Borovykovskyi L., Tvory [Writings], Kyiv: Vyd-vo TsK LKSMU „Molod”, 1971.

Vovk O. V., E'nciklopediya znakov i simvolov [Encyclopedia of Signs and Symbols], Moskva: Veche, 2006.

Zabila V., Do konia [To the Horse], [v]: Ukrainski poety-romantyky. Poetychni tvory [Ukrainian Romantic Poets. Poetry], Kyiv: Naukova dumka, 1987.

Kostomarov M. I., Tvory, v 2 tomakh [Works in 2 Volumes], uporiad., avt. peredmovy ta prymit. V. L. Smilianska, Kyiv: Dnipro, 1990, t. 1.

Franko I. Ya., Zibr. tvoriv, u 50 tomakh [Collected Works, in 50 Volumes], т. 3, red. P.Y.Kolesnyk, Kyiv: Naukova dumka, 1976.

Shevchenko T. H., Povne zibr. tvoriv [Complete collection of Works], u 12 tomakh, redkol. M. Zhulynskyi ta in., Kyiv: Naukova dumka, 2003, t. 1. 